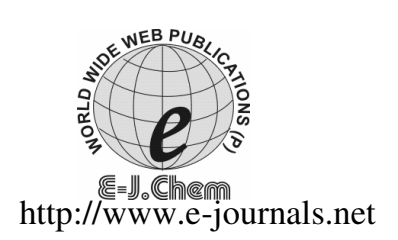

ISSN: 0973-4945; CODEN ECJHAO

E-Journal of Chemistry

2011, 8(1), 37-42

\title{
Estimation of Rabeprazole Sodium and Itopride Hydrochloride in Tablet Dosage Form Using Reverse Phase High Performance Liquid Chromatography
}

\author{
SHAIK.HARUN RASHEED ${ }^{\S *}$ MOGILI.RAMAKOTAIAH ${ }^{\S}$, KONDA.RAVI KUMAR ${ }^{\#}$, \\ C H. NAGABHUSHANAM ${ }^{\mathbb{I}}$ and C H. M.M PRASADA RAO
}

${ }^{\S}$ Department of Pharmaceutics, Donbosco College of Pharmacy

Pulladigunta, guntur 522017, Andhra Pradesh, India

\#Department of Pharmaceutical Chemistry

Siddartha institute of Pharmaceutical Sciences, Jonnalagadda

Narasaraopet, Andhra Pradesh, India

"Department of Pharmacology

KVSR Siddartha College of pharmaceutical Sciences

Vijayawada, Andhra Pradesh, India

Department of Pharmaceutical Chemistry

ST.Anns College of Pharmacy, Chirala, Andhra Pradesh, India

shaikharunrasheed@gmail.com

Received 8 October 2009; Accepted 5 December 2009

\begin{abstract}
A reversed phase high performance liquid chromatography (RP-HPLC) method was developed, validated and used for the quantitative determination of rabeprazole sodium (RP) and itopride hydrochloride (IH), from its tablet dosage form. Chromatographic separation was performed on a Phenomenex C18 column $(250 \mathrm{~mm} \times 4.6 \mathrm{~mm}, 5 \mu \mathrm{m})$, with a mobile phase comprising of a mixture of $50 \mathrm{mM}$ ammonium acetate buffer and methanol $(20: 80 \mathrm{v} / \mathrm{v}), \mathrm{pH} 4.5$ adjusted with acetic acid, at a flow rate of $1.3 \mathrm{~mL} / \mathrm{min}$ with detection at $286 \mathrm{~nm}$. Separation was completed in less than $10 \mathrm{~min}$. As per International Conference on Harmonization (ICH) guidelines the method was validated for linearity, accuracy, precision, limit of quantitation and limit of detection. Linearity of RP was found to be in the range of $37.5-375 \mu \mathrm{g} / \mathrm{mL}$ and $\mathrm{IH}$ was found to be in the range of $5-50 \mu \mathrm{g} / \mathrm{mL}$. The correlation coefficients were 0.9997 and 0.9995 for RB and IH respectively. The accuracy of the developed method was found to be 98.6-100.7 for RP and $99.42-100.81$ for IH. The experiment shows the developed method is free from interference of excipients. It indicates the developed RP-HPLC method is simple, linear, precise and accurate and it can be conveniently adopted for the routine quality control analysis of the tablet dosage form.
\end{abstract}

Keywords: RP-HPLC, Rabaprazole sodium, Itopride hydrochloride, Tablet. 


\section{Introduction}

Rabeprazole sodium is chemically (RP) 2-[[[4-(3-methoxypropoxy)-3-methyl-2-pyridil] methyl] sulfinyl]-1 $H$ - benzimidazole ${ }^{1}$ (Figure 1 ). It has been taken orally to treat gastric acid secretion by inhibiting the parietal cell $\mathrm{H}+/ \mathrm{K}+$ ATP pump and used in short term treatment in healing and symptomatic relief of duodenal ulcers and erosive or ulcerative gastro esophageal reflux disease (GERD); long- term treatment of pathological hypersecretory conditions, including Zollinger-Ellison syndrome and in combination with amoxicillin and clarithromycin to eradicate helicobacter pylori .

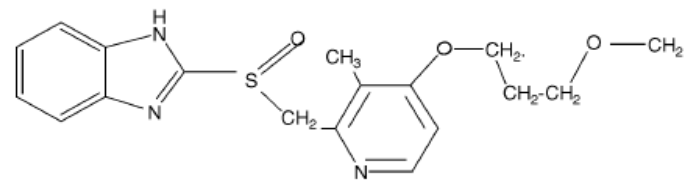

Figure 1. Structure of rabeprazole

Itopride hydrochloride (IH) is chemically $N$-[[4-(2-dimethylaminoethoxy) phenyl] methyl] -3, 4- dimethoxy-benzamide hydrochloride ${ }^{2}$ (Figure 2) used as a prokinetic agent. It acts orally by increasing the acetylcholine concentration, by inhibiting dopamine D2 receptors and acetylcholine esterase. Higher acetylcholine concentration increases the GI peristalsis, increase the lower esophageal sphincter pressure, stimulate the gastric motility, accelerate the gastric empting and improve the gastro duodenal co-ordination

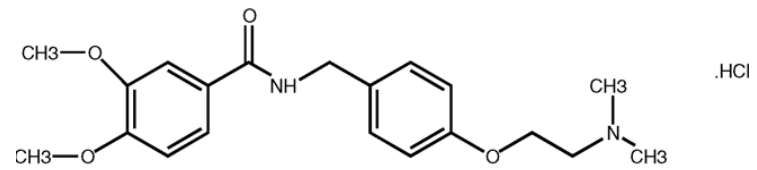

Figure 2. Structure of itopride hydrochloride

The literature survey revealed that several methods have been reported for the individual estimation of rabeprazole sodium and itopride hydrochloride and in combination with other drugs by $\mathrm{UV}^{3-7}$, HPLC $^{8-18}$ and HPTLC ${ }^{19-22}$. However there is no method reported for the simultaneous analysis of the same combination by HPLC. In the present investigation, an economical, precise, accurate reversed phase HPLC method, using a PDA detector, has been developed for the simultaneous quantitative determination of RP and IH from the tablet dosage form.

\section{Experimental}

Bulk drugs RP and IH were procured from Micro labs Ltd, Bangalore, India. Methanol (HPLC grade, purity 99.80\%), acetic acid (AR grade, purity 93.00\%) and ammonium acetate (AR grade, purity 99.50\%) were all procured from Qualigens Fine Chemicals (Mumbai, India). A commercial pharmaceutical preparation (Rablet-IT from the Lupin Pharmaceuticals Mumbai) was used. Its labeled content was RP $20 \mathrm{mg}$ and IH $150 \mathrm{mg}$.

\section{Preparation of stock, working standard and sample solution}

A stock solution each of RP and $\mathrm{IH}(100 \mu \mathrm{g} / \mathrm{mL})$ was prepared by taking $10 \mathrm{mg}$ of each drug, accurately weighed, in separate $100 \mathrm{~mL}$ volumetric flasks. They were dissolved in $25 \mathrm{~mL}$ of mobile phase and then the volume was made up to the mark to get $100 \mu \mathrm{g} / \mathrm{mL}$. The internal standard solution was prepared by taking $10 \mathrm{mg}$ of mosapride in a $100 \mathrm{~mL}$ standard flask. It was dissolved by adding $25 \mathrm{~mL}$ of mobile phase, shaken for few minutes to get a clear solution and the 
final volume was made up to $100 \mathrm{~mL}$. For each drug, appropriate aliquots were pipetted out from the standard stock solution into a series of $10 \mathrm{~mL}$ volumetric flasks to get a concentration of $37.5,75,150,225,300$ and $375 \mu \mathrm{g} / \mathrm{mL}$ of itopride hydrochloride and 5,10 , 20, 30, 40 and $50 \mu \mathrm{g} / \mathrm{mL}$ rabeprazole and $20 \mu \mathrm{g} / \mathrm{mL}$ of mosapride (Internal Standard).

\section{Instruments and chromatographic conditions}

Chromatographic separation was performed on a Shimadzu LC-20 AT HPLC (Double pump) with Rheodyne 7725i type injector with $20 \mu \mathrm{L}$ loop capacity and SPD M20A, Prominence Diode Array Detector. The wavelength of detection chosen was $286 \mathrm{~nm}$. A reverse phase Phenomenex $\mathrm{C} 18$ column $(250 \mathrm{~mm} \times 4.6 \mathrm{~mm}, 5 \mu \mathrm{m})$ was used for the analysis. The mobile phase comprising of a mixture of $50 \mathrm{mM}$ ammonium acetate buffer and methanol $(20: 80 \mathrm{v} / \mathrm{v}), \mathrm{pH} 4.5$ adjusted with acetic acid, at a flow rate of $1.3 \mathrm{~mL} / \mathrm{min}$. The injection volume was $20 \mu \mathrm{L}$.

\section{Method validation}

Every $20 \mu \mathrm{L}$ of the working standard solution of RP in the mass concentration range of 5 to $50 \mu \mathrm{g} / \mathrm{mL}$, and that for $\mathrm{IH}$ in the mass concentration range of 37.5 to $375 \mu \mathrm{g} / \mathrm{mL}$, was injected into the chromatographic system. The chromatograms were developed and the peak area was determined for each concentration of the drug solution. Calibration curves of RP and IH were obtained by plotting the peak area ratio versus the applied concentrations of RP and IH. The linear regression coefficients were found to be 0.9997 and 0.9995 for RP and $\mathrm{IH}$, respectively. Limit of detection (LOD) and limit of quantification (LOQ) were calculated as $3.3 \mathrm{\partial} / \mathrm{S}$ and $10 \mathrm{\partial} / \mathrm{S}$, respectively as per ICH guidelines ${ }^{23}$, where $\partial$ is the standard deviation of the response ( $y$-intercept) and $S$ is the slope of the calibration plot

The instrument precision was performed by injecting $20 \mu \mathrm{L}$ of both RP and IH $(10 \mu \mathrm{g} / \mathrm{mL}$ and $37.5 \mu \mathrm{g} / \mathrm{mL}$ ), in six replicates, into the chromatographic system, under optimized chromatographic conditions. Parameters evaluated were repeatability of peak response of drugs. The relative standard deviations (RSDs) of the peak area were found to be $1.12 \%$ and $1.73 \%$ for RP and IH, respectively.

Repeatability of the method was checked by injecting replicate injections of the combined solution $(10 \mu \mathrm{g} / \mathrm{mL}$ and $37.5 \mu \mathrm{g} / \mathrm{mL}$ of RP and IH respectively). Variability of the method was studied by analyzing the solution on the same day (intra-day precision) and on three different days (interday precision). The results obtained for intra-day precision (RSDs) were $1.12 \%$ and $0.95 \%$, respectively, at $n=6$, for both RP and IH. The inter-day precisions (RSDs) were $0.72 \%$ and $0.45 \%$, respectively, at $n=6$, for both $\mathrm{RP}$ and $\mathrm{IH}$.

Accuracy of the method was tested by carrying out recovery studies at three different spiked levels $(50,100 \%$ and $150 \%)$ on the basis of the label claim. The estimation was carried out as described earlier. At each level, three determinations were performed and results obtained. The amounts recovered and the values of percent recovery were calculated, which are listed in Table 1.

The specificity of the method was checked for the interference of impurities in the analysis of a blank solution (without any sample) and then a drug solution of $20 \mu \mathrm{g} / \mathrm{mL}$ was injected into the column, under optimized chromatographic conditions, to demonstrate the separation of both $\mathrm{RP}$ and IH from any of the impurities, if present. As there was no interference of impurities and also no change in the retention time, the method was found to be specific. 
Table 1. Recovery studies of RP and IH (n=6)

\begin{tabular}{cccccc}
\hline Drug & $\begin{array}{c}\text { Concentration } \\
\text { of std solution } \\
\text { used, } \mu \mathrm{g} / \mathrm{mL}\end{array}$ & $\begin{array}{c}\text { Concentration of } \\
\text { sample solution } \\
\text { added, } \mu \mathrm{g} / \mathrm{mL}\end{array}$ & $\begin{array}{c}\text { Amount found } \\
\mu \mathrm{g} / \mathrm{mL}\end{array}$ & $\begin{array}{c}\% \\
\text { Recovery }\end{array}$ & $\begin{array}{c}\% \\
\text { RSD }\end{array}$ \\
\hline \multirow{3}{*}{$\mathrm{RP}$} & 10 & 5 & 14.80 & 98.66 & 0.463 \\
& 10 & 10 & 20.14 & 100.7 & 0.634 \\
& 10 & 15 & 24.87 & 99.48 & 0.487 \\
$\mathrm{IH}$ & 75 & 37.5 & 112.69 & 100.16 & 0.243 \\
& 75 & 75 & 151.22 & 100.81 & 0.521 \\
& 75 & 112.5 & 186.43 & 99.42 & 0.597 \\
\hline
\end{tabular}

To determine the robustness of the method, experimental conditions such as the composition of the mobile phase, $\mathrm{pH}$ of the mobile phase and flow rate of the mobile phase were altered and the chromatographic characteristics were evaluated. No significant change was observed. System suitability parameters for the method are listed in Table 2.

Table 2. System suitability \& Validation parameters for RP-HPLC

\begin{tabular}{|c|c|c|}
\hline Validation Parameters & $\mathrm{RP}$ & $\mathrm{IH}$ \\
\hline Linearity range, $\mu \mathrm{g} / \mathrm{mL}$ & $37.5-375$ & $5-50$ \\
\hline $\mathrm{r}$ & 0.9997 & 0.9995 \\
\hline $\mathrm{LOD}, \mathrm{ng} / \mathrm{mL}$ & 10 & 2.5 \\
\hline LOQ, ng /mL & 25 & 5 \\
\hline Intra day, \% RSD ${ }^{*}$ & 1.1273 & 0.9557 \\
\hline Inter day, \% RSD ${ }^{*}$ & 0.7253 & 0.4527 \\
\hline Repeatability, \% RSD* & 1.4820 & 0.9568 \\
\hline Accuracy & $98-100 \%$ & $99-100 \%$ \\
\hline Peak purity index & 1.0000 & 1.0000 \\
\hline Resolution factor $\left(\mathrm{R}_{\mathrm{s}}\right)$ & 7.3 & - \\
\hline Asymmetry factor $\left(\mathrm{A}_{\mathrm{s}}\right)$ & \multicolumn{2}{|c|}{0.95} \\
\hline No.of theoritical plates(N) & 3532 & 4666 \\
\hline Capacity factor (K') & 0.601 & - \\
\hline $\begin{array}{l}\text { High equivalent to theoritical } \\
\text { plates( HETP) }\end{array}$ & 33.23 & 43.21 \\
\hline Tailing factor & 1.423 & 1.327 \\
\hline Seletivity factor $(\alpha)$ & \multicolumn{2}{|c|}{3.639} \\
\hline
\end{tabular}

\section{Analysis of formulation}

*Each value is a mean of six observations

Twenty tablets of RP and IH in combination were weighed, their average weight was determined, and finally they were crushed to a fine powder. The tablet powder equivalent to $20 \mathrm{mg}$ of RP and $150 \mathrm{mg}$ of IH was weighed and transferred to a $100 \mathrm{~mL}$ volumetric flask, first dissolved in $50 \mathrm{~mL}$ of mobile phase and then the volume was made up to the mark with the mobile phase. The content was ultrasonicated for $30 \mathrm{~min}$ for complete dissolution. The solution was then filtered using whatman filter paper no 41. The selection of the mixed sample solution for analysis was carried out by the optimization of various dilutions of the tablet dosage form, considering the label claim. The mixed sample solution of $10 \mu \mathrm{g} / \mathrm{mL}$ of RP and $37.5 \mu \mathrm{g} / \mathrm{mL}$ of IH which was falling in the Beer's-Lamberts range with $20 \mu \mathrm{g} / \mathrm{mL}$ internal standard, showed good results and was selected for the entire analysis. The results of tablet analysis $(n=6)$ were found to be $99.20 \%$ with $\pm 0.25 \%$ standard deviation (SD) and $99.52 \%$ 
with $\pm 0.36 \%$ SD for RP and IH respectively. From the typical chromatogram of IH, RP and mosapride (Internal standard) (Figure 3), it was found that the retention time of IH was $2.6 \mathrm{~min}$, RP was $4.2 \mathrm{~min}$ and mosapride was $6.9 \mathrm{~min}$, which were well resolved peaks with a resolution factor of 7.3 and 8.3. The results are shown in Table 3.

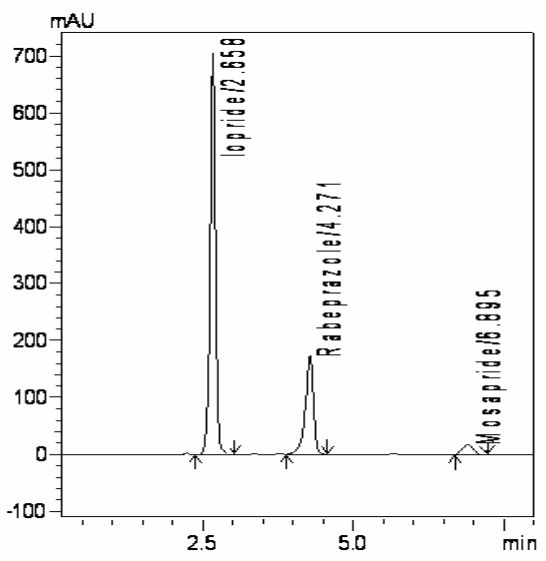

Figure 3. Chromatogram of tablet solution

Table 3. Analysis of Formulation

\begin{tabular}{cccccc}
\hline Formulation & Drug & $\begin{array}{c}\text { Label Claim, } \\
\mathrm{mg} / \mathrm{tablet}\end{array}$ & $\begin{array}{c}\text { Concentration } \\
\text { Taken for } \\
\text { analysis, } \mu \mathrm{g} / \mathrm{mL}\end{array}$ & $\begin{array}{c}\text { Amount } \\
\text { Found, } \mu \mathrm{g} / \mathrm{mL}\end{array}$ & $\begin{array}{c}\% \\
\text { Recovery } \\
(\mathrm{n}=6)\end{array}$ \\
\hline Rablet IT & $\begin{array}{c}\text { Rabeprazole } \\
\text { Itopride }\end{array}$ & 20 & 10 & 9.92 & 99.20 \\
\hline
\end{tabular}

\section{Conclusion}

The developed method was validated in terms of accuracy, repeatability and precision. A good linear relationship was observed for RP and IH in the concentration ranges of $5-50 \mu \mathrm{g} / \mathrm{mL}$ and $37.5-375 \mu \mathrm{g} / \mathrm{mL}$ respectively. The correlation coefficient for RP was found to be 0.9997 and that for IH was 0.9995 . The inter-day and intra-day precision results were good enough to indicate that the proposed method was precise and reproducible. The assay experiment showed that the contents of rabeprazole sodium and itopride hydrochloride estimated in the tablet dosage form were free from the interference of excipients. This demonstrated that the developed HPLC method was simple, linear, precise and accurate, and could be conveniently adopted for the routine quality control analysis of RP and IH, simultaneously, from its pharmaceutical formulation and bulk drug.

\section{References}

1. Budavari S, The Merck Index, $12^{\text {th }}$ Ed., White House Station, NJ, Merck and Co, Inc., 1996, 1392.

2. Dighe $\mathrm{V} \mathrm{V}$, Sane R T, Menon S N and Tambe H, Inamdar S and Pillai S, Indian Drugs, 2006, 43, 282.

3. Sabnis S S, Dhavale N D, Jadhav VY and Gandhi S V, Spectrochimica Acta A, 2008, 69, 849-852.

4. Pattanayak P, Sharma R and Chaturvedi S C, Anal Lett., 2007, 40, 2288-2297. 
5. Heralgi R V, Simpi C C, Kalyane N V and Karajgi S R, Asian J Pharm., 2008, 2, 148.

6. Patel P M, Desai H J, Pate R C and Patel N M, et al. Indian J Pharm Sci., 2007, 69(2), 318-320.

7. Cassia V, Clesio S S, Martin S P and Elfrides E S, J Pharm Biome Anal., 2006, 41, 833-837.

8. Kulkarni V L and Mahulikar P P, et al J Scient Ind Res., 2006, 65(12), 992-994.

9. Patel B H, Suhagia B N, Patel M M and Patel J R, J Chromatogr Sci., 2008, 46, 501-504.

10. Patel B H, Patel M M, Patel J R and Suhagia B N, J Liquid Chromatogr Relat Technol., 2007, 30, 439.

11. Patel B H, Suhagia B N, Patel M M and Patel J R, Acta Chromatographia, 2007, 65, 743-748.

12. Vora A, Damle M, Bhat L and Godge R, Acta Chromatographia, 2007, 66, 941-943.

13. Nicole G M Hunfeld, Richard C J M van Rossen, William P Geus and Daniel J Touw, EJHP Sci., 2008, 14(1), 8-13.

14. Masatomo Miura, Hitoshi Tada, Shigeru S, Tomonori Habuchi and Toshio Suzuki, $J$ Pharma Biomed Anal., 2006, 41, 565.

15. Park C W, Rhee Y S, Go BW, Kam S H, Lee K H, Lee H S and Park E S, Arch Pharm Res., 2008, 31(9), 1195-1199.

16. Takanori H, Kaori S, Hiroaki Y, Hatsushi Y, Tomoyuki K, Shuichi O, Toru S, Nariyasu M and Junichi G, J Chromatography B, 2008, 870(1), 38-45.

17. Toribio L, del Nozal M J, Bernal J L, Alonso C and Jim’enez J J, J Chromatography A, 2005, 109, 118.

18. Ramakrishna N V S, Vishwottam K N, Wishu S, Koteshwara M and Kumar S S, J Chromatography B, 2005, 816(1-2), 209-14.

19. Raval P B, Puranik M, Wadher S J and Yeole P G, Indian J Pharm Sci., 2008, 70(3), 386-390.

20. Patel B H, Suhagia B N, Patel M M. and Jignesh R, J Chromatographic Sci., 2008, 46(4), 304-307.

21. Kaul N, Agrawal H, Maske P, Rao J R, Mahadik K R and Kadam S S, J Sep Sci., 2005, 28, 1566.

22. Suganthi A, John S and Ravi T K, Indian J Pharm Sci., 2008, 70(3), 366-368.

23. International Conference on Harmonization (ICH), Q2B, Validation of Analytical Procedures: Methodology, US FDA Federal Register, 1997, 62. 


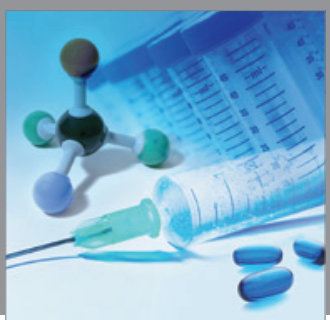

International Journal of

Medicinal Chemistry

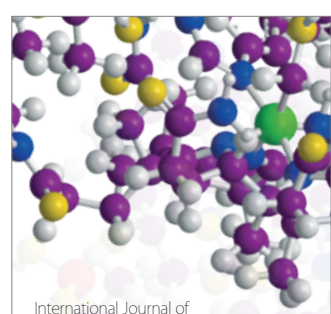

Carbohydrate Chemistry

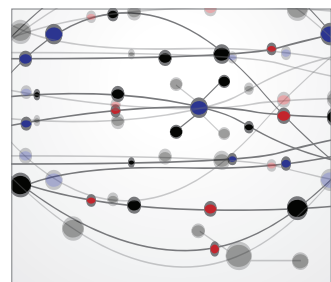

The Scientific World Journal
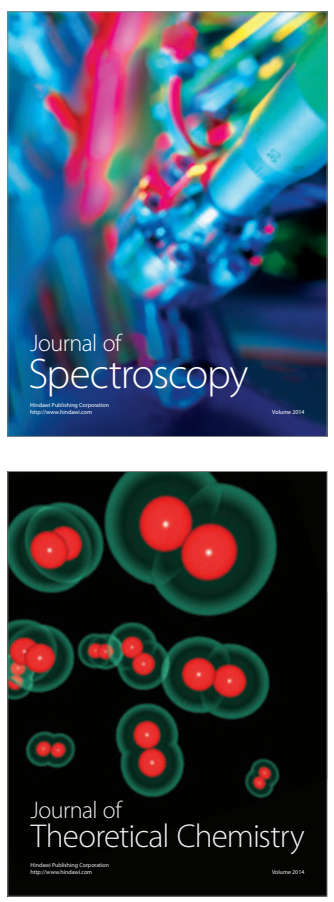
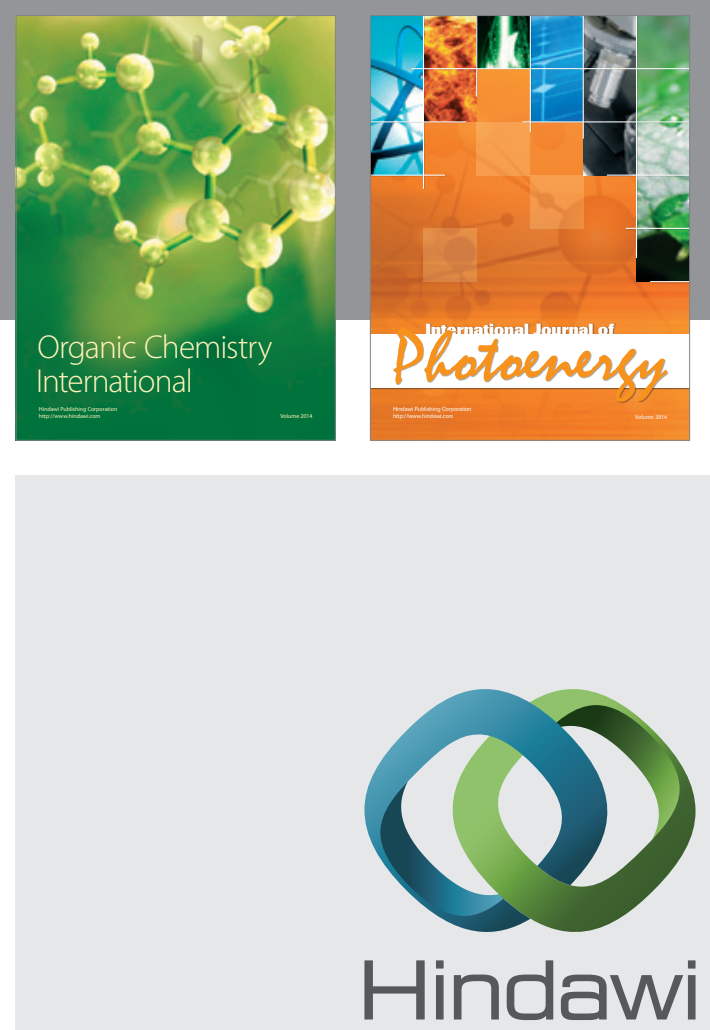

Submit your manuscripts at

http://www.hindawi.com
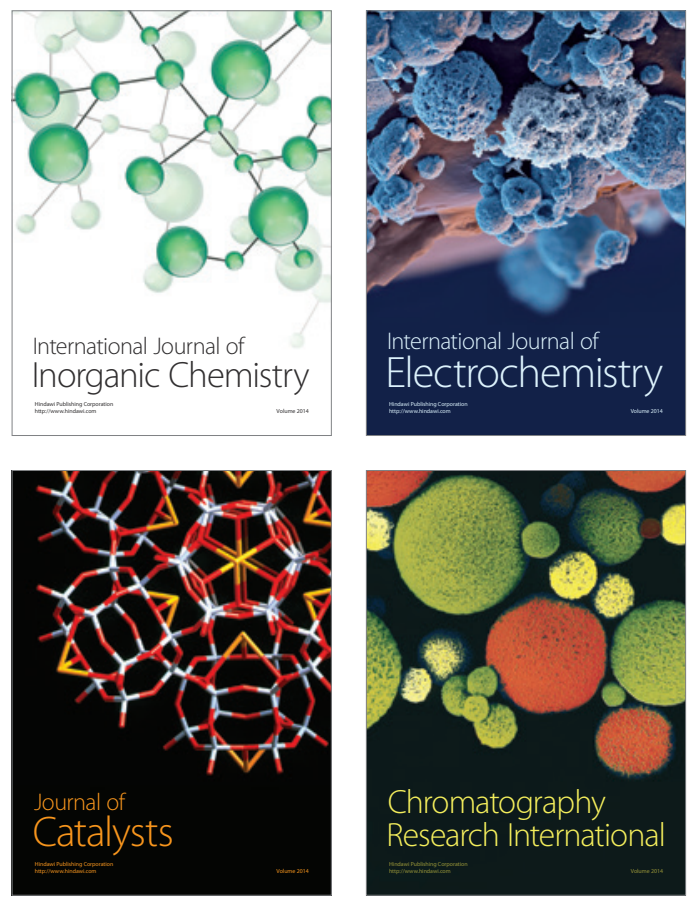
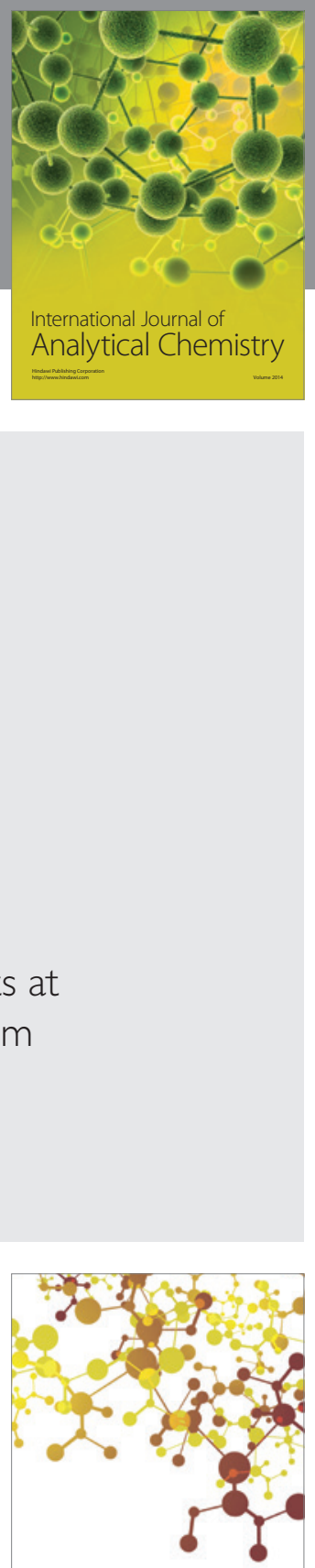

Journal of

Applied Chemistry
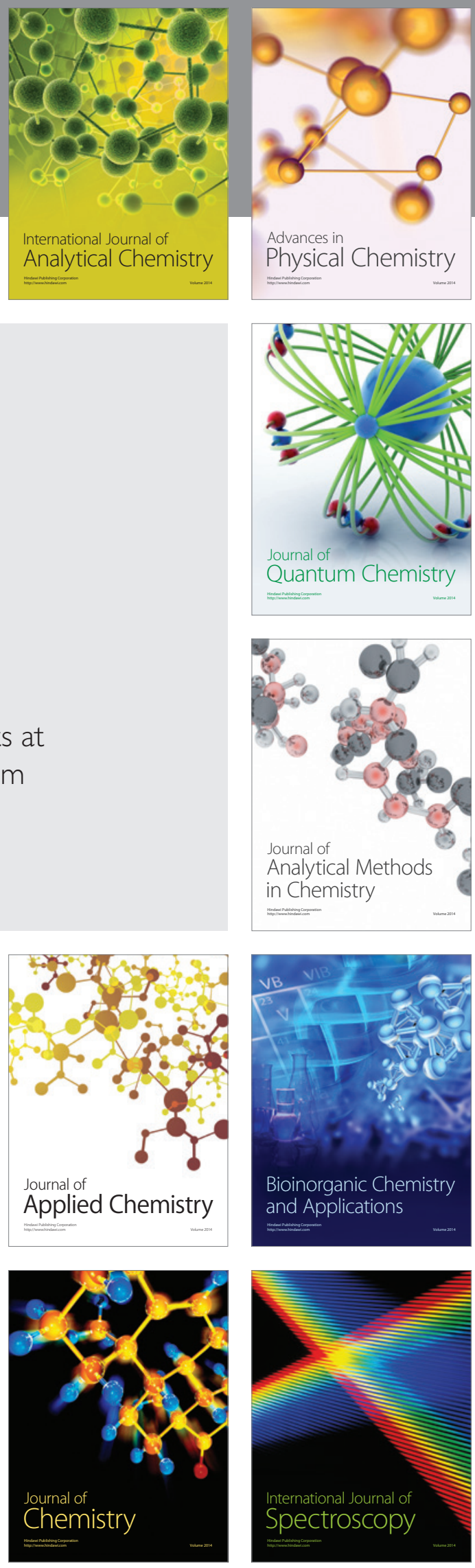